\title{
BCH, an Inhibitor of System L Amino Acid Transporters, Induces Apoptosis in Cancer Cells
}

\author{
Chun Sung KIm, ${ }^{a}$ Seon-Ho ChO, ${ }^{a}$ Hong Sung Chun,${ }^{b, c}$ Sook-Young LeE, ${ }^{c}$ Hitoshi Endou, ${ }^{d}$ \\ Yoshikatsu KANAI, ${ }^{e}$ and Do Kyung KIM ${ }^{*, a}$ \\ ${ }^{a}$ Department of Oral Physiology and The Second Stage of BK21, Chosun University College of Dentistry; 375 Seosuk- \\ dong, Dong-gu, Gwangju 501-759, Korea: ${ }^{b}$ Department of Biotechnology (BK21 Program), Chosun University; \\ ${ }^{c}$ Research Center for Proteineous Materials, Chosun University; 375 Seosuk-dong, Dong-gu, Gwangju 501-759, Korea: \\ ${ }^{d}$ Department of Pharmacology and Toxicology, Kyorin University School of Medicine; 6-20-2 Shinkawa, Mitaka, Tokyo \\ 181-8611, Japan: and ${ }^{e}$ Department of Pharmacology, Osaka University Graduate School of Medicine; 2-2 Yamadaoka, \\ Suita, Osaka 565-0871, Japan. Received February 4, 2008; accepted March 15, 2008; published online March 19, 2008
}

\begin{abstract}
Purpose: L-Type amino acid transporter 1 (LAT1) is highly expressed in cancer cells to support their continuous growth and proliferation. We have examined the effect of 2 -aminobicyclo-(2,2,1)-heptane-2-carboxylic acid (BCH), an inhibitor of system $\mathrm{L}$ amino acid transporters, and the mechanism by which BCH suppresses cell growth in cancer cells. Methods: The effect of $\mathrm{BCH}$ and the mechanism of $\mathrm{BCH}$ on cell growth suppression in cancer cells were examined using amino acid transport measurement, MTT assay, DNA fragmentation analysis, terminal deoxynucleotidyl transferase-mediated dUTP nick end labeling (TUNEL) assay and immunoblotting. Results: BCH inhibited L-leucine transport in a concentration-dependent manner, and it inhibited cell growth in a time-dependent manner in KB human oral epidermoid carcinoma cells, Saos 2 human osteogenic sarcoma cells and C6 rat glioma cells. The formation of a DNA ladder was observed, and the number of TUNELpositive cells was increased with $\mathrm{BCH}$ treatment. Furthermore, the proteolytic processing of caspase- 3 in $\mathrm{KB}$ and C6 cells and of caspase-7 in KB, Saos 2 and $\mathrm{C} 6$ cells was increased by BCH treatment. Conclusion: These results suggest that the inhibition of LAT1 activity by BCH leads to apoptotic cancer cell death by inducing intracellular depletion of neutral amino acids necessary for cancer cell growth.
\end{abstract}

Key words L-type amino acid transporter; cancer cell; apoptosis; 2-aminobicyclo-(2,2,1)-heptane-2-carboxylic acid; anti-cancer therapy

Amino acids are essential to support protein synthesis, which is required for cell growth and proliferation. Amino acid uptake into the cell is mediated by amino acid transporters located on the plasma membrane. ${ }^{1,2)}$

The system L amino acid transporters are an amino acid transport system that transports neutral amino acids, including several essential amino acids, in a $\mathrm{Na}^{+}$-independent manner. ${ }^{1,3)}$ It is a major route for providing living cells, including cancer cells, with amino acids. ${ }^{1,3)}$

We isolated LAT1 (L-type amino acid transporter 1), the first isoform of a system L amino acid transporter, from C6 rat glioma cells. ${ }^{4)}$ Subsequently, we and other researchers cloned LAT2 (L-type amino acid transporter 2), the second isoform of a system $\mathrm{L}$ amino acid transporter. ${ }^{5-7)}$ The structure and function of LAT1 are very similar to those of LAT2. Both isoforms are predicted to be 12-membrane-spanning proteins. ${ }^{4-7)}$ They require an additional single-membranespanning protein, the heavy chain of $4 \mathrm{~F} 2$ antigen $(4 \mathrm{~F} 2 \mathrm{hc})$, for their functional expression in the plasma membrane. ${ }^{4-12)}$ Both LAT1 and LAT2 form a heterodimeric complex via a disulfide bond with 4F2hc. ${ }^{4-12)}$ However, LAT2 is more ubiquitously expressed than LAT1, and it transports not only large neutral amino acids, but also small neutral amino acids in a fashion that appears to have broader substrate selectivity than LAT1. ${ }^{4-7,9-14)}$ In addition, LAT1 is highly expressed in malignant tumors, presumably to support their continuous growth and proliferation. ${ }^{4,8,15,16)}$

2-Aminobicyclo-(2,2,1)-heptane-2-carboxylic acid (BCH) is a model compound for the study of amino acid transporters, as it is a system L selective inhibitor. ${ }^{1,17}$ Because system L amino acid transporters transport neutral amino acids, including several essential amino acids, if they are blocked in living cells by a specific inhibitor such as $\mathrm{BCH}$, the cells would be damaged; damage would be caused specifically by the deprivation of amino acids necessary for protein synthesis, cell growth and proliferation. In addition, several reports have demonstrated that amino acid uptake increased during the proliferation process of cancer cells to support DNA and protein biosynthesis. ${ }^{18-20)}$

It is proposed that the manipulation of system L activity, particularly that of LAT1, would have therapeutic implications. The inhibition of LAT1 activity in cancer cells could be effective in the suppression of cancer cell growth by depriving cancer cells of essential amino acids. ${ }^{17,21)}$ However, the mechanism by which inhibition of LAT1 can cause cancer cell growth suppression or cytotoxicity of cancer cells is not entirely clear.

In this study, we examined the effect of $\mathrm{BCH}$ on cell growth and its mechanism of cell growth suppression in cancer cells. We used cells that highly expressed only LAT1 among all the system $\mathrm{L}$ transporters. ${ }^{22-24)}$ Our results show that the system L selective inhibitor $\mathrm{BCH}$, at suitable concentrations, can induce the suppression of cell growth and cancer cell apoptosis.

\section{MATERIALS AND METHODS}

Materials $\left[{ }^{14} \mathrm{C}\right] \mathrm{L}$-Leucine was purchased from PerkinElmer Life Sciences Inc. (Boston, MA, U.S.A.). BCH and 3[4,5-dimethylthiazol-2-yl]-2,5-diphenyltetrazolium bromide (MTT) were purchased from Sigma (St. Louis, MO, U.S.A.). The terminal deoxynucleotidyl transferase-mediated dUTP 
nick end labeling (TUNEL) assay kit (DeadEnd ${ }^{\mathrm{TM}}$ Colorimetric TUNEL System) and caspase-3 antibody were purchased from Promega Co. (Madison, WI, U.S.A.) and Cell Signaling Technology, Inc. (Danvers, MA, U.S.A.), respectively. KB human oral epidermoid carcinoma cells, Saos2 human osteogenic sarcoma cells and C6 rat glioma cells were provided by the American Type Culture Collection (ATCC; Rockville, MD, U.S.A.).

Cell Cultures The KB cells were grown in MEM containing NEAA (non-essential amino acids) at a ratio of $100: 1$, and the media was supplemented with 5\% FBS. The Saos 2 cells and C6 cells were grown in the DMEM supplemented with $10 \%$ FBS. All cells were maintained as monolayers in plastic culture plates at $37^{\circ} \mathrm{C}$ in a humidified atmosphere containing $5 \% \mathrm{CO}_{2}$.

Transport Measurements in Cells To examine the inhibition of amino acid transport by $\mathrm{BCH}$ in cells, uptake experiments were performed using $\left[{ }^{14} \mathrm{C}\right] \mathrm{L}$-leucine, one of the substrates of system L amino acid transporters, as described previously. ${ }^{17,22)}$ Because the uptake of amino acids induced by system $\mathrm{L}$ amino acid transporters is not dependent on $\left.\mathrm{Na}^{+}, 4,7,8,13\right)$ the uptake experiments were performed in $\mathrm{Na}^{+}$free uptake solution (125 mM choline-Cl, $4.8 \mathrm{~mm} \mathrm{KCl}, 1.3 \mathrm{~mm}$

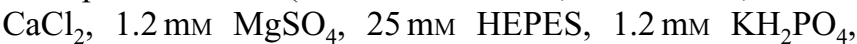
$5.6 \mathrm{~mm}$ glucose, $\mathrm{pH} 7.4)$. The cells were maintained in growth medium at $37^{\circ} \mathrm{C}$ in $5 \% \mathrm{CO}_{2}$. The cells were collected and seeded on 24 -well plates $\left(1 \times 10^{5}\right.$ cells/well $)$ in fresh growth medium. The uptake measurements were performed when the cells reached approximately $85-95 \%$ confluence on 24-well plates. After the removal of growth medium, the cells were washed three times with $\mathrm{Na}^{+}$-free uptake solution and pre-incubated for $10 \mathrm{~min}$ at $37^{\circ} \mathrm{C}$. Then, the medium was replaced by the uptake solution containing $\left[{ }^{14} \mathrm{C}\right] \mathrm{L}-$ leucine. Because the uptake of $\left[{ }^{14} \mathrm{C}\right] \mathrm{L}$-leucine induced by system $\mathrm{L}$ amino acid transporters was time-dependent and exhibited a linear dependence on the incubation time up to $1 \mathrm{~min},{ }^{17,22}$ the uptake measurements were performed for 1 min. Uptake was terminated by removing the uptake solution followed by washing three times with ice-cold uptake solution. Then, cells were solubilized with $0.1 \mathrm{~N} \mathrm{NaOH}$, and radioactivity was counted by liquid scintillation spectrometry. The values are expressed as percentage of activity. For the measurement of the uptake of $\left[{ }^{14} \mathrm{C}\right] \mathrm{L}$-leucine, four to six wells of cells were used for each data point. To confirm the reproducibility of the results, three separate experiments were performed for each measurement. Results from the representative experiments are shown. To determine the $\mathrm{IC}_{50}$ value for $\mathrm{BCH}$, the uptake of $1 \mu \mathrm{M}\left[{ }^{14} \mathrm{C}\right] \mathrm{L}$-leucine was measured in the presence of $\mathrm{BCH} 0,1,3,10,30,100,300,1000$ and $3000 \mu \mathrm{M}$.

Inhibition of Cell Growth by BCH (MTT Assay) The cell viability test was performed according to the previouslydescribed method, ${ }^{25,26)}$ with minor modifications. The cells were seeded at a concentration of $5 \times 10^{3}$ cells/well in 24 -well plates. After $24 \mathrm{~h}$ growth, the cells were treated with $\mathrm{BCH}$ at various concentrations and incubation times. The cell viability was assessed using MTT assay. Three separate experiments were performed for each concentration/exposure time combination.

DNA Fragmentation Analysis Following treatment with $20 \mathrm{~mm} \mathrm{BCH}$ for various incubation times, approxi- mately $5 \times 10^{6}$ cells were collected and transferred to lysis buffer containing $100 \mathrm{~mm} \mathrm{NaCl}, 10 \mathrm{~mm}$ EDTA, $300 \mathrm{~mm}$ Tris$\mathrm{HCl}, \mathrm{pH} 7.5,200 \mathrm{~mm}$ sucrose, $0.5 \%$ SDS and $0.5 \mathrm{mg} / \mathrm{ml}$ proteinase $\mathrm{K}$ and incubated at $65^{\circ} \mathrm{C}$. DNA was extracted with an equal volume of phenol/chloroform/isoamylalcohol $(25: 24: 1, \mathrm{v} / \mathrm{v})$ and precipitated with ethanol. The DNA was resuspended in Tris-EDTA buffer, $\mathrm{pH} 8.0$ containing $5 \mu \mathrm{g} / \mathrm{ml}$ DNase-free RNase and incubated at $37^{\circ} \mathrm{C}$ for $1 \mathrm{~h}$. The DNA was visualized on $1.5 \%$ agarose gel in the presence of $0.5 \mu \mathrm{g} / \mathrm{ml}$ ethidium bromide.

TUNEL Assay To examine cellular apoptosis induced by $\mathrm{BCH}$ treatment, the TUNEL assay was performed. The cells were seeded at a concentration of $5 \times 10^{3}$ cells/well in 24-well plates. After $24 \mathrm{~h}$ growth, the cells were treated with $20 \mathrm{~mm} \mathrm{BCH}$ at various incubation times. The TUNEL assay was performed using a DeadEnd ${ }^{\mathrm{TM}}$ Colorimetric TUNEL System kit (Promega Co., Madison, WI, U.S.A.) in accordance with the manufacturer's instructions.

Immunoblotting The cells were treated with $20 \mathrm{~mm}$ $\mathrm{BCH}$ at various incubation times. Immunoblotting was performed according to the previously-described method, ${ }^{27,28)}$ with minor modifications. The anti-caspase- 3 or anti-caspase-7 antibody (1:1000 dilution, Cell Signaling Technology, Inc., Danvers, MA, U.S.A.) was used as the primary antibody.

Determination of Caspase Activation The activity of caspase-3/7 was determined using the cell-permeable fluorogenic substrate PhiPhiLux- $\mathrm{G}_{1} \mathrm{D}_{2}$ (OncoImmunin, Inc., Gaithersburg, MD, U.S.A.), which was used according to the manufacturer's instructions, and visualized by fluorescence microscopy.

Data Analysis All experiments were performed in triplicate. Results are presented as mean \pm S.E.M. Statistical significance was analyzed by using Student's $t$-test for two groups and one way analysis of variance for multi-group comparisons. $p<0.05$ is considered statistically significant.

\section{RESULTS}

Inhibition of $\left[{ }^{14} \mathbf{C}\right] \mathrm{L}-$ Leucine Uptake by $\mathrm{BCH}$ In order to examine which $\mathrm{BCH}$ concentration effectively inhibits Lleucine uptake in cancer cells, $\left[{ }^{14} \mathrm{C}\right] \mathrm{L}$-leucine $(1 \mu \mathrm{M})$ uptake was measured in the presence of various $\mathrm{BCH}$ concentrations $(0,1,3,10,30,100,300,1000,3000 \mu \mathrm{M})$. As shown in Fig.

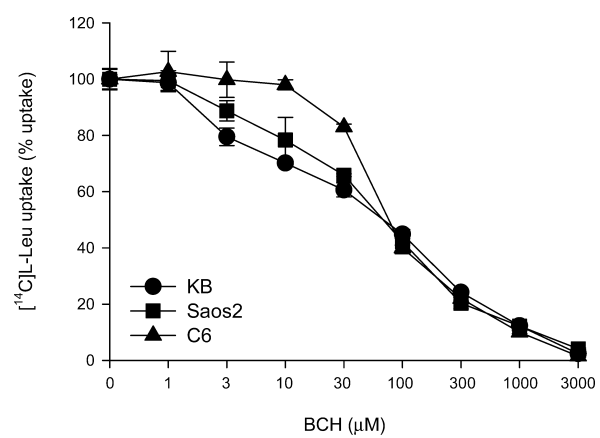

Fig. 1. Concentration-Dependent Inhibition of $\left[{ }^{14} \mathrm{C}\right] \mathrm{L}-$ Leucine Uptake by $\mathrm{BCH}$ in $\mathrm{KB}$, Saos2 and C6 Cells

$\left[{ }^{14} \mathrm{C}\right] \mathrm{L}$-Leucine uptake $(1 \mu \mathrm{M})$ was measured for $1 \mathrm{~min}$ in the presence of various $\mathrm{BCH}$ concentrations in $\mathrm{KB}$ (filled circle), Saos2 (filled square) and C6 cells (filled triangle), and is expressed as a percentage of the control-L-leucine uptake in the absence of $\mathrm{BCH}$. Each data point represents the mean \pm S.E.M. for three experiments. 
(A)

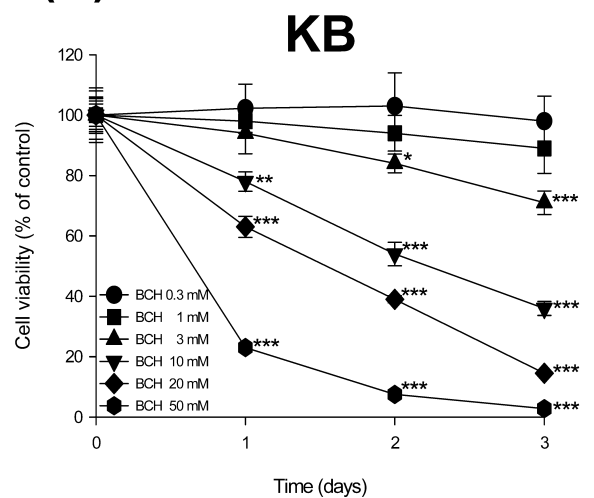

(B)

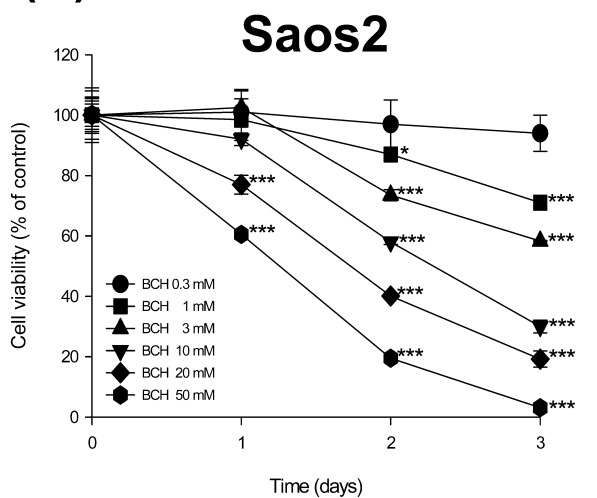

(C)

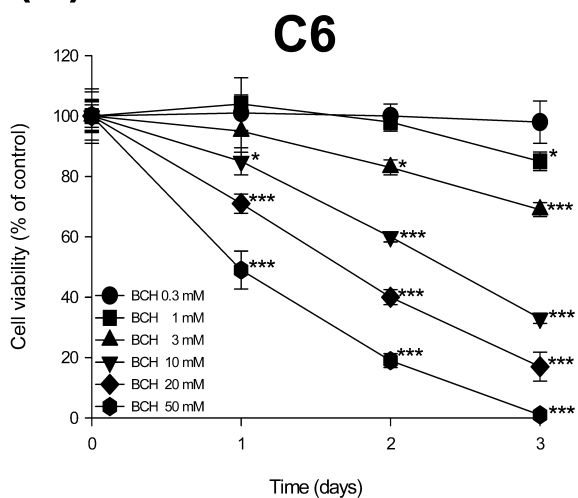

Fig. 2. Time-Dependent Effects of BCH on Cell Viability in KB, Saos2 and C6 Cells

The KB (A), Saos2 (B) and C6 (C) cells were treated with 0.3, 1, 3, 10, 20 and $50 \mathrm{~mm} \mathrm{BCH}$ for $0-3 \mathrm{~d}$. Cell viabilities were determined by the MTT assay. The percentage of cell viability was calculated as a ratio of $\mathrm{A} 570 \mathrm{~nm}$ of $\mathrm{BCH}$ treated cells and untreated control cells. Each data point represents the mean \pm S.E.M. for three experiments. $* p<0.05 v s$. control, ** $p<0.01 v s$. control and $* * * p<0.001 v s$. control (the control cells were measured in the absence of BCH treatment).

Table 1. Antiproliferative Effect of BCH in Cancer Cells

\begin{tabular}{lccc}
\hline \hline & \multicolumn{3}{c}{$\mathrm{IC}_{50}(\mathrm{~mm})$} \\
\cline { 2 - 4 } & $1 \mathrm{~d}$ & $2 \mathrm{~d}$ & $3 \mathrm{~d}$ \\
\hline $\mathrm{KB}$ & $33.1 \pm 3.8$ & $13.7 \pm 0.9$ & $6.9 \pm 0.4$ \\
Saos2 & $>50$ & $15.2 \pm 1.8$ & $5.6 \pm 0.7$ \\
C6 & $>50$ & $15.2 \pm 1.8$ & $6.5 \pm 0.9$ \\
\hline
\end{tabular}

Cells were incubated with or without $\mathrm{BCH}$ for $0,1,2$ and $3 \mathrm{~d}$.

1, BCH $(1-3000 \mu \mathrm{M})$ inhibited the $\left[{ }^{14} \mathrm{C}\right] \mathrm{L}-$ leucine $(1 \mu \mathrm{M})$ uptake in a concentration-dependent manner with $\mathrm{IC}_{50}$ values of $75.3 \pm 6.7 \mu \mathrm{M}$ (KB cells), 78.8 $\pm 3.5 \mu \mathrm{M}$ (Saos 2 cells) and $73.1 \pm 4.5 \mu \mathrm{M}$ (C6 cells).

Cancer Cell Growth Inhibition by BCH To analyze the effect of $\mathrm{BCH}$ on the viability of cancer cells, the cells were treated with $\mathrm{BCH}$ at various concentrations and incubation times, and then the MTT assay was performed. From 0.3 to $50 \mathrm{~mm}$ treatment of $\mathrm{BCH}$, the inhibition of cancer cell growth depended on the $\mathrm{BCH}$ treatment time (Fig. 2). When the cells were treated with $\mathrm{BCH}$ at $0.3,1,3,10,20$ and $50 \mathrm{~mm}, \mathrm{BCH}$ inhibited the proliferation of cancer cells in a dose-dependent manner (Fig. 2). The $\mathrm{IC}_{50}$ value for each time point of $\mathrm{BCH}$ treatment is shown in Table $1 . \mathrm{BCH}$ had similar cytotoxicities and $\mathrm{IC}_{50}$ values in all three cancer cell types (Table 1).

DNA Fragmentation and TUNEL Assays Increased cellular apoptosis is only one among several possible mechanisms involved in reduced cell proliferation. To determine if apoptosis is indeed the underlying mechanism for the reduced cell proliferation we had observed, the cancer cells treated with $\mathrm{BCH}$ were subjected to DNA fragmentation and TUNEL assays. As shown in Fig. 3A, the formation of a DNA ladder in the $\mathrm{KB}$, Saos2 and C6 cells treated with $20 \mathrm{~mm}$ BCH was observed in a time-dependent manner. As expected, the proportion of TUNEL-positive KB, Saos 2 and C6 cells was significantly increased with $20 \mathrm{~mm} \mathrm{BCH}$ treatment compared with untreated control (Fig. 3B).

Activation of Caspases by $\mathbf{B C H}$ in Cancer Cells The levels of procaspase- 3 and procaspase- 7 were examined by Western blot analysis and detected by fluorescence microscopy using a selective fluorogenic substrate since caspase- 3 and caspase- 7 are effector caspases of apoptotic cell
(A)
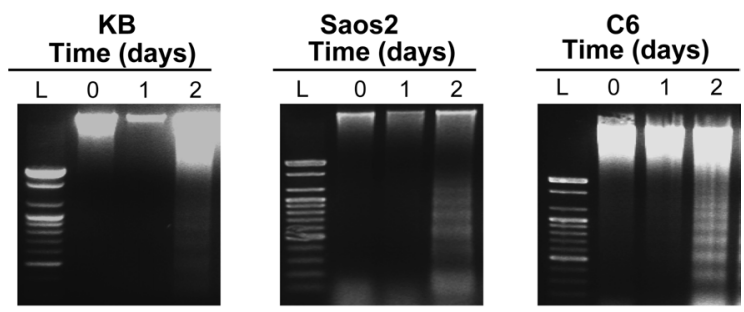

(B)
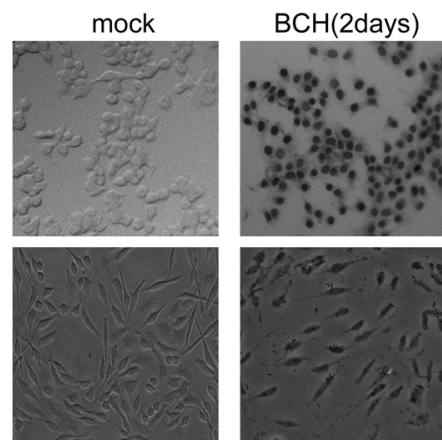

$\mathrm{KB}$

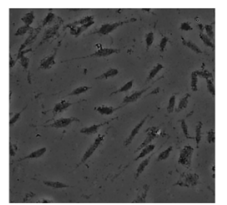

Saos2
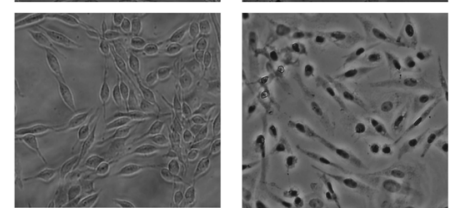

C6

Fig. 3. Apoptosis Induced by $\mathrm{BCH}$ in $\mathrm{KB}$, Saos2 and C6 Cells

(A) Fragmentation of internucleosomal DNA by $\mathrm{BCH}$. The cells were treated with $20 \mathrm{~mm} \mathrm{BCH}$ for the indicated time periods and nuclear DNA was subjected to agarose gel electrophoresis. (B) TUNEL assay. The KB, Saos2 and C6 cells were treated with $20 \mathrm{~mm} \mathrm{BCH}$ for the indicated time periods, and the TUNEL assay was performed. The number of TUNEL-positive cells was increased with $20 \mathrm{~mm} \mathrm{BCH}$ treatment compared with untreated control in the KB, Saos2 and C6 cells.

death. Treatment with $20 \mathrm{~mm} \mathrm{BCH}$ significantly promoted proteolytic cleavage of procaspase- 7 in the KB, Saos 2 and C6 cells, with a decrease in the amount of procaspase-7 (Fig. 4). In addition, $\mathrm{BCH}$ enhanced proteolytic cleavage of procaspase- 3 in the $\mathrm{KB}$ and $\mathrm{C} 6$ cells, with a decrease in the amount of procaspase-3; however, this change was not observed in the Saos 2 cells (Fig. 4). Furthermore, activation of caspase-3/7 in BCH-treated cells (KB, Saos2 and C6) was confirmed by fluorescence microscopy using fluorogenic sub- 
strate. As shown in Fig. 5, BCH treatment led to activate the caspase- $3 / 7$ in the KB, Saos 2 and C6 cells.

\section{DISCUSSION}

In this study, we investigated the effects of $\mathrm{BCH}$ on cell growth and its mechanism of growth suppression in cancer cells. In our previous studies, ${ }^{22-24)}$ we examined the expression of the system $\mathrm{L}$ amino acid transporters in several cancer cell types. The KB human oral epidermoid carcinoma cells and C6 rat glioma cells expressed only LAT1 with 4F2hc but not LAT2 in the plasma membrane, and the Saos2 human osteogenic sarcoma cells mainly expressed LAT1 with 4F2hc,

\section{KB Saos2 C6}

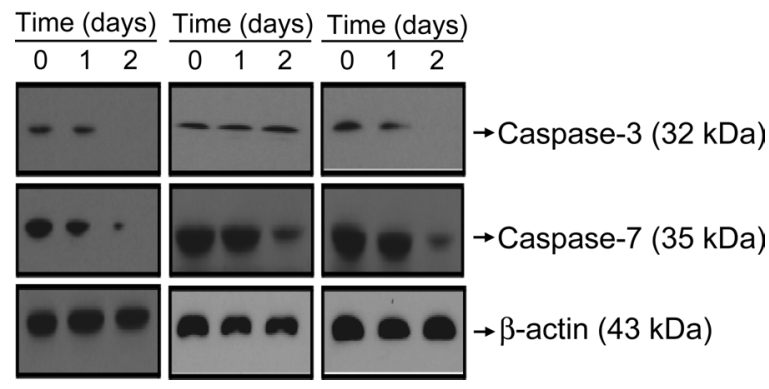

Fig. 4. Proteolytic Cleavage of Procaspase- 3 and Procaspase- 7 by $\mathrm{BCH}$ Treatment in KB, Saos2 and C6 Cells

$\mathrm{BCH}$-induced activity of procaspase- 3 and procaspase- 7 was measured in the cell types. The cells were treated with $20 \mathrm{~mm} \mathrm{BCH}$ for the indicated time periods. The cell lysate was prepared and analyzed by Western blot analysis as described in Materials and Methods. with weak expression of LAT2. We used the KB, Saos2 and C6 cells for this study.

$\mathrm{BCH}$ is an amino acid-related compound that has been used as a selective inhibitor of the system $\mathrm{L}$ amino acid transporters, including LAT1 and LAT2. ${ }^{1,17)}$ In this study, BCH completely inhibited L-leucine uptake, as a model neutral amino acid, in a concentration-dependent manner with similar $\mathrm{IC}_{50}$ values in the KB, Saos2 and C6 cells (Fig. 1). This result suggests that LAT1 plays an important role in neutral amino acid transport, including L-leucine transport, in cells that highly express LAT1 only.

In the MTT assay, BCH inhibited cell growth in a time-dependent manner in the KB, Saos 2 and C6 cell types (Fig. 2). This corresponded with the results of several compounds (paradol, norcantharidin, baccatin, etc. $)^{25,29,30)}$ that have anticancer effects via the suppression of cancer cell growth in a time-dependent manner. LAT1 is upregulated in cancer cells to support their continuous growth and proliferation. ${ }^{4,8,15,16)}$ LAT1 was also highly expressed in these cells, and neutral amino acids were transported for cell growth and proliferation. If the activity of LAT1 was inhibited by $\mathrm{BCH}$, the intracellular depletion of neutral amino acids, including essential amino acids necessary for cell growth, may be induced. The results suggest that cancer cell growth was inhibited. As shown in Fig. 1, although $3 \mathrm{~mm} \mathrm{BCH}$ completely inhibited leusine uptake, it was not enough to suppress the cell growth and apoptosis. We speculated that uptake experiment is short term view but apoptosis induction is long term view because $\mathrm{BCH}$ compete with extracellular amino acid and slowly induced apoptosis via caspase activation. In order to detect

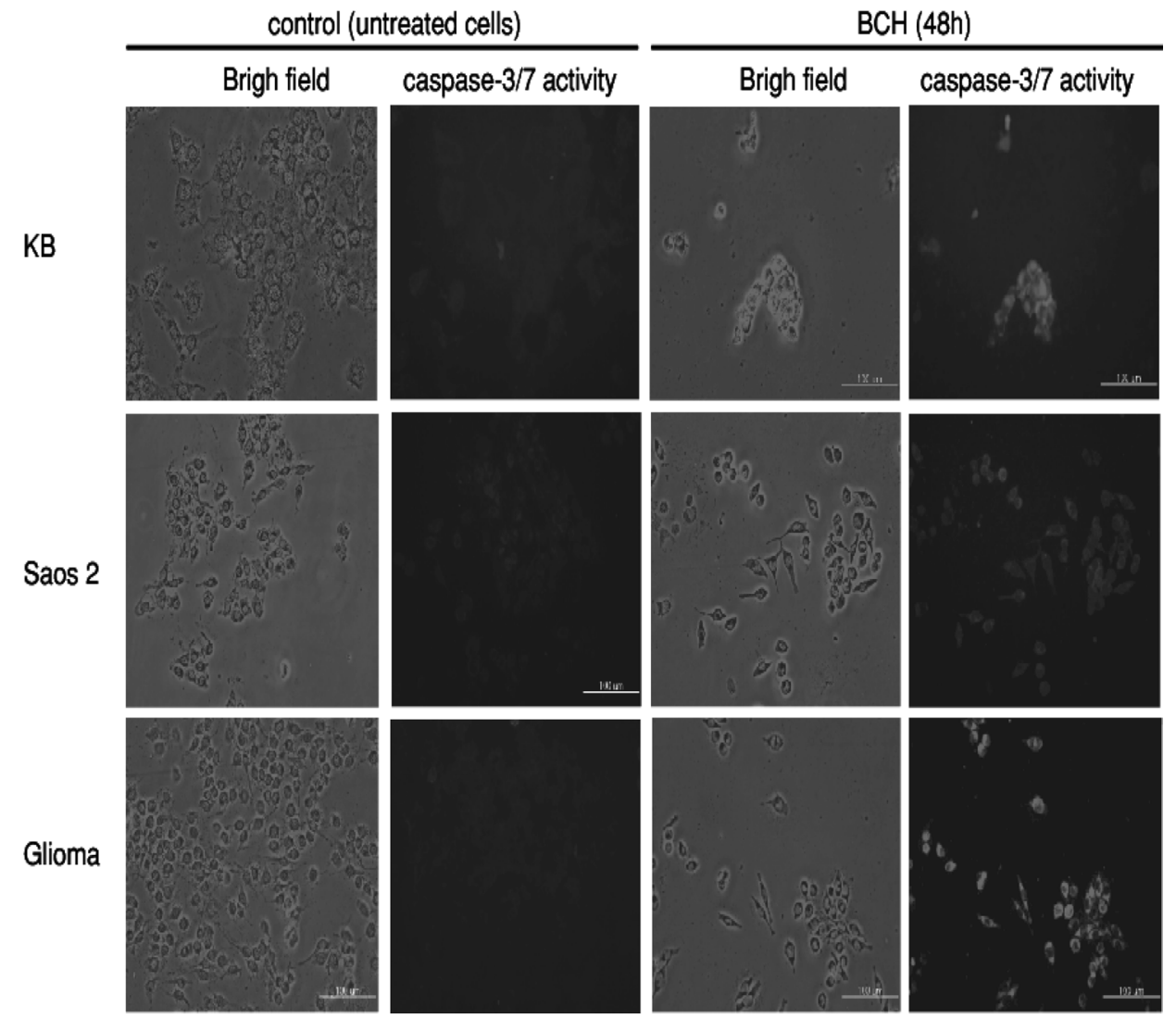

Fig. 5. Activation of Caspase-3/7 by BCH Treatment in Living Cells (KB, Saos2 and C6)

The cells were treated with $20 \mathrm{~mm} \mathrm{BCH}$ for $48 \mathrm{~h}$ and added specific cell-permeable substrate Phiphilux $\mathrm{G}_{1} \mathrm{D}_{2}$. Activity of caspase-3/7 was visualized by fluorescence microscopy. 
apoptosis, high concentration of $\mathrm{BCH}$ was needed for inhibition of highly proliferous cancer cells.

In this study, treatment with $\mathrm{BCH}$ induced internucleosomal DNA fragmentation and the increase of TUNEL-positive cells in $\mathrm{KB}$, Saos 2 and $\mathrm{C} 6$ cells, suggesting apoptotic cell death (Fig. 3). These results indicate that $\mathrm{BCH}$ inhibited the growth of these cells by activating cell apoptosis.

The activation of a family of intracellular cysteine proteases, called caspases, is known to play an important role in the initiation and execution of apoptosis induced by various stimuli. ${ }^{31,32)}$ Among the caspases identified in mammalian cells, caspase- 3 and caspase-7 may serve as effector caspases of apoptotic cell death. ${ }^{31-33)}$ Caspase-3 and caspase-7 are synthesized as inactive proenzymes (of sizes $32 \mathrm{kDa}$ and $35 \mathrm{kDa}$, respectively), which require proteolytic activation. $^{31-33)}$ Our results show that high levels of procapase-7 were present in $\mathrm{BCH}$-untreated cancer cells, and the amount of procaspase-7 was decreased after $\mathrm{BCH}$ treatment in the KB, Saos2 and C6 cells (Fig. 4). Our results also showed that $\mathrm{BCH}$ treatment promoted proteolytic cleavage of procaspase3 in the KB and C6 cells, with a decrease in the amount of procaspase-3, but this was not seen in the Saos2 cells (Fig. 4). These results suggest that $\mathrm{BCH}$ induces apoptotic cell death through caspase-3- and caspase-7-dependent processing in $\mathrm{KB}$ and $\mathrm{C} 6$ cells, while on the other hand, $\mathrm{BCH}$ induces apoptotic cell death only through caspase-7-dependent processing in Saos2 cells (Fig. 5). The mechanisms of apoptosis induced by $\mathrm{BCH}$ are not yet completely understood. Further studies will reveal the precise cellular and molecular mechanisms of apoptosis induced by $\mathrm{BCH}$.

In conclusion, we found that inhibition of the amino acid transporter LAT1 by BCH led to apoptotic cell death in cancer cells by inducing intracellular depletion of essential neutral amino acids such as L-leucine. Moreover, LAT1 could be a new target for suppression of the growth of cancer cells.

Acknowledgements This study was supported by a grant from the National R\&D Program for Cancer Control, Ministry of Health \& Welfare, Republic of Korea (0720240). We thank Su Young Kim for her helpful technical support.

\section{REFERENCES}

1) Christensen H. N., Physiol. Rev., 70, 43-77 (1990).

2) McGivan J. D., Pastor-Anglada M., Biochem. J., 299, 321-334 (1994).

3) Oxender D. L., Christensen H. N., Nature (London), 197, 765-767 (1963).

4) Kanai Y., Segawa H., Miyamoto K., Uchino H., Takeda E., Endou H., J. Biol. Chem., 273, 23629-23632 (1998).

5) Pineda M., Fernandez E., Torrents D., Estevez R., Lopez C., Camps M., Lloberas J., Zorzano A., Palacin M., J. Biol. Chem., 274, 1973819744 (1999).
6) Rossier G., Meier C., Bauch C., Summa V., Sordat B., Verrey F., Kuhn L. C., J. Biol. Chem., 274, 34948-34954 (1999).

7) Segawa H., Fukasawa Y., Miyamoto K., Takeda E., Endou H., Kanai Y., J. Biol. Chem., 274, 19745-19751 (1999).

8) Yanagida O., Kanai Y., Chairoungdua A., Kim D. K., Segawa H., Nii T., Cha S. H., Matsuo H., Fukushima J., Fukasawa Y., Tani Y., Taketani Y., Uchino H., Kim J. Y., Inatomi J., Okayasu I., Miyamoto K., Takeda E., Goya T., Endou H., Biochim. Biophys. Acta, 1514, 291302 (2001).

9) Mannion B. A., Kolesnikova T. V., Lin S.-H., Thompson N. L., Hemler M. E., J. Biol. Chem., 273, 33127-33129 (1998).

10) Mastroberardino L., Spindler B., Pfeiffer R., Skelly P. J., Loffing J., Shoemaker C. B., Verrey F., Nature (London), 395, 288-291 (1998).

11) Pfeiffer R., Spindler B., Loffing J., Skelly P. J., Shoemaker C. B., Verrey F., FEBS Lett., 439, 157-162 (1998).

12) Nakamura E., Sato M., Yang H., Miyagawa F., Harasaki M., Tomita K., Matsuoka S., Noma A., Iwai K., Minato N., J. Biol. Chem., 274, 3009-3016 (1999)

13) Uchino H., Kanai Y., Kim D. K., Wempe M. F., Chairoungdua A., Morimoto E., Anders M. W., Endou H., Mol. Pharmacol., 61, 729-737 (2002).

14) Rajan D. P., Kekuda R., Huang W., Devoe L. D., Leibach F. H., Prasad P. D., Ganapathy V., Biochim. Biophys. Acta, 1463, 6-14 (2000).

15) Sang J., Lim Y.-P., Panzia M., Finch P., Thompson N. L., Cancer Res., 55, 1152-1159 (1995).

16) Wolf D. A., Wang S., Panzia M. A., Bassily N. H., Thompson N. L., Cancer Res., 56, 5012-5022 (1996).

17) Kim D. K., Kanai Y., Choi H. W., Tangtrongsup S., Chairoungdua A., Babu E., Tachampa K., Anzai N., Iribe Y., Endou H., Biochim. Biophys. Acta, 1565, 112-121 (2002).

18) Ohkame H., Masuda H., Ishii Y., Kanai Y., J. Surg. Oncol., 78, 265272 (2001)

19) Medina M. A., Sánchez-Jiménez F., Márquez J., Rodríguez Q. A., Núñez de Castro I., Mol. Cell. Biochem., 113, 1-15 (1992).

20) Wasa M., Bode B. P., Abcouwer S. F., Collins C. L., Tanabe K. K., Souba W. W., Ann. Surg., 224, 189-197 (1996).

21) Kanai Y., Endou H., Curr. Drug Metab., 2, 339-354 (2001).

22) Yoon J. H., Kim Y. B., Kim M. S., Park J. C., Kook J. K., Jung H. M., Kim S. G., Yoo H., Ko Y. M., Lee S. H., Kim B. Y., Chun H. S., Kanai Y., Endou H., Kim D. K., Cancer Lett., 205, 215-226 (2004).

23) Kim S. G., Kim H. H., Kim H. K., Kim C. H., Chun H. S., Kanai Y., Endou H., Kim D. K., Anticancer Res., 26, 1989-1996 (2006).

24) Kim D. K., Kim I. J., Hwang S., Kook J. H., Lee M. C., Shin B. A., Bae C. S., Yoon J. H., Ahn S. G., Kim S. A., Kanai Y., Endou H., Kim J. K., Neurosci. Res., 50, 437-446 (2004).

25) Keum Y. S., Kim J., Lee K. H., Park K. K., Surh Y. J., Lee J. M., Lee S. S., Yoon J. H., Joo S. Y., Cha I. H., Yook J. I., Cancer Lett., 177, $41-47$ (2002).

26) Kim S., Nah S. Y., Rhim H., Biochem. Biophys. Res. Commun., 365, $399-405$ (2008).

27) Kondo K., Kaneko T., Baba M., Konno H., Biol. Pharm. Bull., 30, $633-637$ (2007).

28) Kuge Y., Takai N., Ishino S., Temma T., Shiomi M., Saji H., Biol. Pharm. Bull., 30, 1634-1640 (2007).

29) Kok S. H., Hong C. Y., Kuo M. Y., Lee C. H., Lee J. J., Lou I. U., Lee M. S., Hsiao M., Lin S. K., Oral Oncol., 39, 19-26 (2003).

30) Miller M. C., 3rd, Johnson K. R., Willingham M. C., Fan W., Cancer Chemother. Pharmacol., 44, 444 452 (1999).

31) Datta R., Kojima H., Yoshida K., Kufe D., J. Biol. Chem., 272, 20317-20320 (1997).

32) Liu X., Zou H., Slaughter C., Wang X., Cell, 89, 175-184 (1997).

33) Cohen G. M., Biochem. J., 326, 1-16 (1997). 